
RECORD

Stretching scales? Risk and sociality in climate finance

Environment and Planning A: Economy and Space

\title{
Brett Christophers
}

Uppsala University

\section{Patrick Bigger}

Lancaster University

\section{Leigh Johnson}

University of Oregon

\section{Introduction}

In September 2017, two apparently unconnected and apparently unremarkable events transpired in the world of climate finance. New York's Metropolitan Transit Authority issued a $\$ 662$ million green bond, the sixth in a multi-billion dollar series of bonds to finance its major capital spending program. The bond's green labelling came at a premium for investors, who accepted lower yields than those offered by traditional bonds in exchange for its projected mitigating influence on greenhouse gas emissions decades in the future (Environmental Finance, 2018). The same month, Hurricanes Irma and Maria triggered \$54 million in immediate payouts from the multi-country Caribbean Catastrophe Risk Insurance Facility (CCRIF) to ten Caribbean governments whose territories bore immense storm damages. ${ }^{1}$ The CCRIF's 20 member countries pay premiums into a regional pool, capitalized by a multi-donor trust fund, which triggers payouts based on extreme event parameters. Neither September event was a first-of-its-kind. Rather, both embody a phenomenon we argue is becoming "ordinary" in certain strains of climate finance: stretching the temporal and spatial scales over which climate risk pools are constituted.

\footnotetext{
${ }^{1}$ See details in Table 1.
} 
In their new book, Climate Leviathan (2018), Joel Wainwright and Geoff Mann wrestle with the potential implications of climate change for the existing global political order. The key premise of the book is that the territorial nation-state is fundamentally inadequate, both individually and collectively, to address the climate crisis in any meaningful fashion. Wainwright and Mann therefore argue that one way or another the future will see profound and widespread processes of rescaling of political authority. The most likely form of such rescaling, they suggest, is a "stretching", eventuating in the emergence of the eponymous Leviathan: that is, a capitalist planetary sovereign.

If Climate Leviathan belongs to the possibilistic future, we suggest in this article that other processes of climate change-related rescaling, likewise consisting of a form of stretching, may already be underway. These processes belong to the realm not of politics, but of finance; and not of authority, but of risk. Examining two different types of climate finance - one, sovereign catastrophe insurance pools, geared to adaptation, and the other, green (climate) bond financing, geared principally to mitigation - the article focuses on the risk pools that these mechanisms serve to constitute. By "risk pools", we refer to those social constituencies whose fortunes (broadly defined) the financial products in question are designed to, in one way or another, help derisk. Examples of such constituencies from beyond the climate finance realm, occurring at a range of different scales, might be an individual in the case of a contributions-based private pension plan, a company's workforce in the case of an employment-based health insurance scheme, or a nation in the case of a welfare state insurance model. All such risk pools, notably, have a temporal and geographical as well as social scale, pertaining respectively to the duration and location of the underlying risks.

In line with and shaped by the cross-scalar manifestations of climate change itself - its refusal to respect society's territorial boundaries and its exhortation for current generations to pay heed to the fortunes of those that will follow - the two climate-related financial mechanisms examined in this article tend, we suggest, to index expansive risk socialities, spatialities and temporalities. They stretch the socialities and space-times over which risk is constituted. To the degree that they fund mitigation of climate-change risk for 
one, and locally, they propose to fund it for all, everywhere and (in theory, at any rate) for always ${ }^{2}$ in spreading the risks inherent in adapting to climate change, they aggregate peoples, places and periods into new, combinatory constellations.

The significance of this stretching, the article maintains, is that it goes against the scalar grain of the neoliberal era. The past four decades have seen a pronounced "risk shift", at least in Western societies (e.g. Prasch, 2004; Hacker, 2006a). This has entailed a compression or "squeezing” of the spatialities, temporalities and socialities indexed, or aggregated, by key forms of financial risk. In the days of the Keynesian welfare state, there was considerable truth to the idea that, from a risk perspective, people really were "all in this together", to use the phrase employed, unintentionally-ironically, in 2009 by the then British Prime Minister David Cameron; individuals were part of large, often nationally-constituted, risk pools of various descriptions. Today, by contrast, people (and places and times) generally are not all in this together, if by "this" we understand - as the article suggests we should - the strategic orientation to future uncertainties that is afforded by different forms of financial risk. "Today," Hacker (2006a: x) writes, "the message is starkly different: You are on your own." In short, risk has increasingly been privatized and individualized, and the spatialities and temporalities it indexes have been compressed accordingly. The climate-related financial mechanisms we examine in this paper are distinctive, then, specifically for reversing this historical trend. They are not about individualization and compression. They gesture at and aim to achieve the opposite.

This, note, emphatically does not mean a return to welfare state-era risk management. The climate finance mechanisms we examine stretch risk over wider socialities, but in doing so they do not occasion the substantive redistribution of vulnerability that was intrinsic to Keynesian welfare institutions, where the less vulnerable explicitly subsidized the more vulnerable (however imperfectly). Scale per se, as Doreen Massey long argued, is value free. To assume that the 'global' is necessarily more progressive than the 'local' - or

\footnotetext{
${ }^{2}$ We do not make this claim in the same way as proponents of carbon offsets, who maintain that each ton of carbon dioxide (or its equivalent in other greenhouse gases, c.f. MacKenzie, 2009) is intrinsically fungible. We understand that the context of emissions matters, as do the co-pollutants emitted in industrial processes (Lohmann, 2010). The mechanisms under consideration here are not aiming to create markets wherein representations of specific quantities of greenhouse gases, abstracted from their social realities, are swapped; instead, our focus, specifically in our discussion of green bonds, is on the risks attached to unavoided future emissions and on the pooling thereof.
} 
indeed vice versa - or that stretched socialities of risk are necessarily 'better' than narrow ones would be to accede to crude scalar fetishism (Massey, 1991). Analogously, there is a world of difference between Climate Leviathan, Wainwright and Mann's capitalist planetary sovereign, and Climate Mao, their hypothetical non-capitalist planetary sovereign, even as the two share a common scalar configuration. In our case, what matters is how risk pools, whatever their scalar framing, are managed and mobilized. Capitalist financial institutions can and do profit from expansively constituted risks, just as they can from individualized ones. Yet they do so in different ways.

The article proceeds in three main sections. The first provides theoretical framing. It establishes the basic contention that finance, among other things, involves the constitution of risk pools with particular socialities, spatialities and temporalities. The second section reviews the historic squeezing of risk under neoliberalism, showing how, most notably, in two key financial spheres - insurance and savings, especially for retirement (i.e. pensions) - risk has increasingly been individualized. The third and main section of the article then considers the stretching of risk's scale ventured by certain strains of climate finance: their attempt not only to stem the tide of risk individualization but to push it backwards. We look at sovereign catastrophe insurance pools and green bonds in turn. The arguments that appear in the empirical section are based on ongoing research in the sovereign catastrophe insurance and green bonds markets, including document content analysis, participant observation within industry events and networks, and key informant interviews. $^{3}$

Before proceeding, three brief caveats are in order. First, the claims presented in this article relate to two specific types of climate finance mechanism, not to climate finance in general. In particular, carbon markets, perhaps the best-known climate finance mechanism and also the most widely documented in the geographical literature (Boyd, 2009; Bumpus and Liverman, 2008; Knox-Hayes, 2013; Lohmann, 2010;

\footnotetext{
${ }^{3}$ Though we do not draw heavily on interview data in this article, interviews conducted with key interlocutors and market participants in both markets corroborate the theoretical argument made here. For green bonds, 11 in-person interviews were conducted between May and December 2017 with issuers, verifiers, purchasers, and stock exchanges in Washington D.C., London, and Copenhagen. For sovereign catastrophe insurance pools, 12 in-person and telephone interviews were conducted between September 2015 and October 2017 with sovereign pool managers, bilateral donors, development bank strategists, and in-country drought managers in London, New York, Frankfurt, and Nairobi.
} 
Newell et al, 2012), are beyond our remit. ${ }^{4}$ Second, we are interested only in the scale of the risk pools constituted by these mechanisms, not the efficacy (or otherwise) of the mechanisms themselves. In the case of climate-related insurance mechanisms, for example, important recent work questions the actual "adaptive" effects (e.g. Müller et al, 2017; Action Aid, 2017; Wrathall, 2015); we do not dispute such findings, but nor do they gainsay our argument. Third, our argument is, perforce, somewhat speculative: the two mechanisms we examine are both relatively new, which means conclusiveness about their implications is, at this stage, impossible.

\section{Risk, sociality, and spatio-temporality}

Definitions of "finance" abound, as do understandings of what "financial" activities involve, ranging from the specific - supplying or raising money or capital - to the much more general - the conduct of monetary matters. For the classical political economists, finance, and the interest income it generated, was a tax on value creation, an inherently unproductive activity that, at best, could enhance the productivity of genuinely productive labours through efficiently targeted investment. Prior to the neoclassical turn, in any event, the question of risk was barely on the radar of scholars of finance. That all changed with Frank Knight's Risk, Uncertainty and Profit (1921), which became, and remains, a touchstone of mainstream financial economics. Only much more recently, meanwhile, has risk also become a central problematic for critical political economists of finance (e.g. Martin et al, 2008; Christophers, 2015).

It is the risk dimensions of finance, as opposed say to finance's role in creating, extracting or transferring value, that concern us in this article (which is not to say that risk is more important than those other issues, nor indeed that it is unconnected to them). Perhaps Knight's most important contribution was to demonstrate that capitalist finance is indelibly about risk. If risk in general is conceived as a probabilistic orientation to the future, then financial assets are forms of financial risk insofar as they price the probabilities of different futures: the value (and reliability) of scheduled future interest payments in the case of debt instruments, for instance, or the value of projected future profits in the case of equities. In doing so, they

\footnotetext{
${ }^{4}$ Regulatory carbon trading has little to do with environmental risk. Any environmental benefits that accrue through cap-and-trade markets are achieved through the cap, not the trade.
} 
commodify uncertainty - in Knight's terms, random outcomes with unknowable probabilities - as risk random outcomes with knowable probabilities. Indeed, financial instruments are perhaps the quintessential products of those modern capitalist "practices, techniques and rationalities" that, in Mitchell Dean's (1998: 25 ) words, "seek to make the incalculable calculable."

More specifically, the article is concerned with what we labeled in the introduction "risk pools"risk's embodied social constituencies, and their geographical and temporal (as well as social) scale. It is important to be clear from the outset about the specific nature of the risk socialities, geographies and temporalities that the article does and does not address. The word "constituency" is key here because our focus is indeed on risks as constituted, not (also) as distributed. An example, from beyond the world of climate finance, can help parse these crucial distinctions.

Consider the notorious US sub-prime mortgage. At the time of its issue, the risk embedded in this asset has a narrow social constituency (the individual mortgagor, who, as both borrower and homeowner, is both the subject and object of the risk) and an equally narrow geographical scale (the individual mortgaged property), with a temporal scale defined by the mortgage lifetime. The distribution of this risk is a different matter: the mortgagee, perhaps a bank, may be local, for example, but it need not be. Both the constitution and distribution of risk become altogether more complicated, however, if, as occurred widely in the run-up to the global financial crisis, the mortgage is subsequently securitized. If it is bundled together with other mortgages, a new risk asset - a mortgage-backed security (MBS) - is created, now with a collective social constituency (all relevant mortgagors) and a potentially much more complicated cartography (the bundled mortgages could all be from one town, but need not be). In terms of risk distribution, the new asset can be bought and held by investors literally anywhere, as it was of course in the pre-crisis period.

The point of fleshing out this example is simply this: in this article, with its examination of climate finance mechanisms, we are interested only in the scales - social, geographical and temporal - of risk in its constitution, not its distribution. If mortgages and MBSs were our concern, in other words, we would be interested in the identity, location and mortgaged lifetime of the relevant mortgagors, not with where - on whose balance sheets, in which countries - these financial risks end up being held. The question, then, is not 
who profits from creating, distributing or owning financial assets, but rather whose futures/"fortunes" such assets corral: in our respective cases of sovereign catastrophe insurance pools and climate bonds, whose risk the insurance insures, and against whose risk the use of bond proceeds is intended to mitigate.

The example of insurance can help to reinforce the key point that financial risk, as constituted, always has a spatiality and temporality as well as a sociality. Through insurance, we, as individuals, seek to offset the potential costs of disagreeable future events. But insurance companies typically do not treat us as isolated individuals in providing insurance. They treat us as part of a population of insurees, across whom risk can be spread. "Insurance can only cover groups," François Ewald (1991: 203) writes; "it works by socializing risks. It makes each person a part of the whole. ... Insurance's characteristic operation is the constitution of mutualities." This does not mean that individuals are not recognized and insured as individuals; it simply means that their individuality is strictly relative. "The risk defines the whole, but each individual is distinguished by the probability of risk which falls to his or her share." The individuality of insurees is always "relative to that of other members of the insured population."

The "constitution of mutualities" effected by insurance has two crucial features for our purposes. The first is that the scale of these mutualities, of the risk groups (or pools) defined and created by insurers, varies. "The work of the insurer is, precisely," Ewald says "to constitute that population by selecting and dividing risks" (ibid). In doing so, it creates social scale, even if this scale - that of the insured population to which we belong - is often (but not always) "abstract" in the sense that it lacks the consciousness of, in Ewald's words, those "qualitative" mutualities, like family or nation, to which we know we belong. And second, these mutualities always have a geographical and temporal as well as social scale. Over what time horizon are we tethered to others in our risk pool? Where are those others located, and thus what spaces and places does the insurance product bring together? In other words, insurance, as Paul Bennett (2009) intimates, is a technology, inter alia, for the (re)constitution of geographical and temporal scale. The broader point looking beyond insurance in particular to financial instruments in general - is that financial risk, pace Shaun French (2008: 394), can "only ever be understood in the context of its particular spatialities and 
temporalities." This, therefore, is how we endeavor to understand climate-related financial risk in what follows.

\section{The neoliberal squeeze}

The development and growth of "climate finance" of various types in recent years has occurred against the backdrop of a deep-seated post-1970s historical transformation in key forms of financial risk. Commentators including Robert Prasch and Jacob Hacker have referred to this as Western capitalism's great "risk shift." More than anything else, this shift has entailed risk's individualization. Risk has been individualized in two significant ways.

Firstly, "negative" risks - the risk of unemployment, ill-health, death and so on - increasingly have been devolved to individuals and their families, as the previous bearers of those risks, like governments and employers, have relinquished them. Prasch (2004: 405), for example, says "we have seen, and can expect to continue to see, the systematic shifting of risks toward those who cannot afford them, cannot control them, and do not want them." Hacker (2006b), in turn, reckons that this intensified onus on the individual to shoulder and manage "the economic risks of modern capitalism" is "the defining economic transformation of our times."

The second trend towards individualization, which is the one we are primarily interested in here, is connected to this first development yet distinct from it. It concerns the social scale at which risks, of all types, are constituted. Who, in short, does risk - as a technology for engaging with the future - bring together? Whose futures does it collectively (or not) encompass and connect? The question of whether mechanisms for managing future uncertainties connect the uncertainties of my future to the uncertainties of yours is not the same as the question of whether the government or an employer on the one hand, or you and I on the other, are charged with bearing those uncertainties, even if the two questions are related.

Our main goal in this section, therefore, is to show that since the 1970s, risks historically constituted across, and thus connecting, often large groups of people have increasingly been disassembled and recontracted at narrower social scales - if not always at the scale of the individual, then certainly tending in 
that direction. This second trend towards individualization is connected to the former one inasmuch as it has resulted in significant measure from the large scale - albeit uneven - retraction of state responsibility for economic life under neoliberalism. The retraction of the state, after all, is the retraction of the primary social institution with "the means - and, often, the incentive - to require participation in broader risk pools" (Hacker, 2006b).

Hacker writes insightfully about this historical transformation in risk's social scale. In the context specifically of negative risks, and specifically of the US experience, he contrasts postwar "risk socialization" mechanisms with contemporary "risk privatization." The pivotal difference, Hacker (2004: 249) says, lies in "the scope of shared risk - the degree to which potent threats to income are spread across citizens of varied circumstances (risk socialization) or left to individuals or families to cope with on their own (risk privatization)." Nikolas Rose (1996) makes a comparable case. When, under Keynesian welfarism, the state assumed various risks, it did so, Rose says, at the scale of and "in the name of society" (338). But as risk is increasingly individualized, and thus is not only devolved to individuals but transformed into the discrete property and quality of individuals, the "economic fates of citizens within a national territory are uncoupled from one another" (339). Social space, insofar as it is stitched together by risk, is rent asunder. Even if "the social" constituted by Keynesian risk-pooling technologies was always somewhat imbalanced, imperfect and unjust insofar as it was characterized by distinctive gender, race and class-based fault-lines and exclusions (Lehtonen and Liuokko, 2015), the individualization of risk under neoliberalism is nonetheless part-andparcel of the concomitant "death of the social" diagnosed by Rose.

As Rose further observes, the de-socialization associated with the neoliberal rescaling of risk has also been a re-spatialization. In historically connecting wider groups of people, risk connected the places where those people lived and worked, making them part of a single geographic space defined by risk. "The social, overarching all its stratifications and variations, was imagined as a single space, territorialized across a nation. Correlatively, government 'from the social point of view' posited a single matrix of solidarity," Rose (ibid: 333) writes. But the decomposition of shared social risks into a fragmented landscape of individual risks has inevitably led to risk's localization. “Today, in contrast, a diversity of 'communities' is thought to, 
actually or potentially, command our allegiance: moral communities ... lifestyle communities ... communities of commitment" - and of course communities, rather than societies, of risk. "Such communities are construed as localized, heterogeneous, overlapping and multiple" (ibid).

For both Rose and Hacker, there are two prime examples of financial risk's de-socialization under neoliberalism: insurance (especially of health) and saving (especially for retirement). We will briefly discuss each of these.

In the West, the late nineteenth and first half of the twentieth centuries saw the consolidation of what Paul Bennett (2009) calls "solidarity-based" systems of insurance (c.f. Lehtonen and Liuokko, 2015). By this he means systems that spread risk across what Hacker, cited above, calls "citizens of varied circumstances." In such systems, "there is cross-subsidisation between different risk groups. ... It is a solidarity system because risks are the responsibility of the whole of society, not just those people with a similar risk profile. This system is inherently redistributive" (Bennett, 2009: 224-225). Early examples of such solidarity-based systems were the working-class friendly societies. Originated in the nineteenth century primarily to insure workers against the risks of labour, these societies "absorbed local risk pools into more highly organised networks of membership, ritual, and support," and, in the case of the United Kingdom, claimed some six million members (double that of the labour unions) by 1911 (Rodgers, 2009: 218-219). This solidarization trend - the stretching of the scale at which risk was constituted - culminated, of course, in the social insurance model of the postwar welfare state, which obviated much (but not all) of the need for friendly societies and comparable non-state mutual-assistance organizations. Now, the risk pool was national. Under neoliberalism, however, the national risk pool has been savagely fragmented. Where the welfare state model "urges strong central government to create large and undifferentiated risk pools that foster social responsibility," the individualizing insurance model characteristic of neoliberalism "urges differentiated risk pools, based on market segmentation and ability to pay, that foster individual responsibility" (Ericson et al, 2003: 6). The social scale at which risk is constituted is radically circumscribed, "aimed at placing the individual in the insurance equivalent of a gated community, sharing risks only with those who are similarly situated" (ibid: 227). There is no cross-subsidisation between those 
with different risk "profiles." This model perforce makes financial exclusion more likely because some people cannot meet the cost of the risk that they - individually - are deemed to represent. Hence there is, as Ericson et al (2003: 227) say, "a direct relationship among market segmentation, unpooling risk, and redlining the undesirable." There is, furthermore, a distinctive geography to risk's re-scaling and the exclusions it occasions. Here is Bennett (2009: 226) on the Thatcherite attacks on welfare-state social insurance in 1980s Britain:

Such attacks on state solidarity systems attempted to define the geography of social and economic responsibility much more narrowly by identifying and limiting the people towards whom one had responsibilities. First, they made a claim about the appropriate scale of responsibility. Individuals, families and neighbours are where welfare can best be provided and can best be exercised, not the scale of 'society'. Less extreme versions emphasised the importance of community.

In the context of the present article, a particularly salient example of the shift from socialized to individualized insurance models concerns flood insurance. In both the UK and the US, subsidies have historically been built into what were, effectively, solidarity-based insurance systems with largely undifferentiated risk pools. But advocates of flood-risk individualization have long maintained the merits of, in one's words, confronting "every individual prospect for a flood plain location explicitly with the cost his flood plain location would entail" (cited in Collier, 2013: 285). Such "confrontation", and thus the social and geographical differentiation of flood risk, has increasingly been enforced. In the UK, for example, the government reported in 2013: "Commercial pressures and the availability of more sophisticated flood risk models are creating a trend towards insurers increasingly assessing local flood risk and imposing at least partially risk-reflective terms. ... $22 \%$ of policyholders in areas of significant flood risk were already paying a premium which is reflective of their flood risk by January 2011” (DEFRA, 2013: 13). Similarly in the US, the 2012 reform of the National Flood Insurance Program mandated "actuarially fair" rates and revised flood maps to redefine 65,000 more properties as falling in "high-risk" flood zones (NRC, 2015).

Post-1970s developments in health insurance have followed a comparable pattern. In the UK, the National Health Service (NHS) "broadly fits the ideal type of a solidarity system" (Bennett, 2009: 225). But 
it has come under increasing pressure, and private health insurance has expanded, especially during the Thatcherite period, with the number of private policies growing from around $1 \mathrm{~m}$ in 1978 to around 3.5m by the mid-1990s (Propper et al, 2001: 182). Private health insurance creates narrow risk pools containing people of assumed equivalent risk, and it prices them accordingly. One factor differentiating these variablypriced pools, and thus connecting the individuals within them, is geographic location - hence the term “postcode lottery." US health insurance has also experienced a post-1970s drift towards individualization. While there has never been an American NHS, the US has long had what Hacker (2004: 257) calls "private systems of risk socialization.” In the health-insurance context, the most important, historically, were employment-based schemes "provided by large commercial and non-profit insurers, which pooled risks across many workplaces" (ibid: 252). But the neoliberal era and its de-socialization imperative has seen "a marked narrowing of the bounds of collective protection" in US health insurance (254). Finely-grained risk segmentation, by geography and other parameters, aimed at setting premiums to accurately reflect each individual's expected healthcare costs, is the order of the day. But, of course, as Linda Blumberg (2004: 2) argues, "gains from segmenting healthy groups can occur only if premium costs for the unhealthy are increased, or if the unhealthy are excluded." And this, prior to Obamacare, is what happened, the proportion of US persons without health insurance rising from c. 11 percent in the 1970 s to c. 16 percent by $2010 .^{5}$ Meanwhile, a parallel squeezing of risk's constitutive scale has occurred in the savings realm. The most commonly-cited example is savings for retirement, but it is not the only one. The abovementioned friendly societies, which played such a key role in providing solidarity-based approaches to financial risk in the first half of the twentieth century, typically offered members savings (and credit) as well as insurance facilities. But their neoliberal successors are very different beasts where the scale of risk aggregation is concerned. Devoid of the catholicity of their forebears, today's community credit unions, observes Bennett (2009: 226), "are formed at the scale of locality of residence or workplace, and allow people to access credit from pooled savings.” They are by very definition vehicles of risk segmentation, "a vote for an ethic of [narrow community over wider social] solidarity, and an attempt to delimit the geography of responsibility.

\footnotetext{
${ }^{5}$ https://ourworldindata.org/grapher/percentage-of-persons-without-health-insurance-coverage-us.
} 
... [T] here are to be no cross-subsidies between different risk groups; communities are left to their own fates" (ibid: 227). Indeed there was a fittingness to the fact that UK credit unions received formal legal legitimation, in the shape of the Credit Unions Act, in 1979: they are quintessential creatures of Thatcherite neoliberalism.

Since the 1970s, schemes for savings for retirement have undergone profound transformation in the capitalist world. The most important shift has been from social security-based pension systems to systems based on individual pension investment accounts. The former, which dominated until the 1980 s, were typically financed on a "pay as you go" (PAYG) basis. "Money to pay benefits comes in on a "pay-as-yougo' or rolling basis," explains Orenstein (2008: 16), "rather than up front, as in a 'funded' system," which is the type of system most countries have transitioned to. As Orenstein notes, PAYG systems rely on a "collective ethos and a variety of forms of redistribution" (17). And the solidarity is not just social and being national - spatial; it is also temporal. Insofar as "pension payments to current pensioners are financed from the pension contributions of current employees," PAYG is fundamentally "based on the principle of intergenerational solidarity" (Altiparmakov, 2013: 90): financial risk is collectively constituted across time, with working generations funding the retirement of their predecessors. In recent decades, however, this principle has been dissolved as countries have moved away from PAYG - sometimes wholly replacing traditional social security systems with systems based on individual accounts, and sometimes moving to mixed or parallel systems (Orenstein, 2008: 26-27; Hacker, 2004: 254-256). Systems based on investment accounts are "funded" in the sense that the money invested during an individual's working life funds their own subsequent retirement. They are also individualizing; they "individualize risks and returns": "If you suffer an incapacitating illness or injury, your investment account stops growing” (Orenstein, 2008: 17). This world of widespread financial-risk individualization, then, is the world into which modern-day climate finance has emerged.

\section{Climate finance: stretching risk's scales?}

Sovereign catastrophe insurance pools 
Whereas the scale of sociality of the Keynesian insurance pool was that of the nation state, recent initiatives to buffer the impacts of extreme events and increase countries' financial stability in the face of the same have generated an experimental patchwork of regional socialities exceeding the territorial boundaries of nation states. These include the African Risk Capacity (ARC) agency, a specialized agency of the African Union; the Caribbean Catastrophe Risk Insurance Facility (CCRIF); and the Pacific Catastrophe Risk Insurance Company (PCRIC) $)^{6}$. Table 1 provides an overview of program features and pool members. Although such “sovereign risk pools" - particularly the Caribbean and Pacific initiatives - also insure against non-weather linked events such as earthquakes and tsunamis, they are endorsed as global best practice policy models for comprehensive weather risk management in the face of climate change (eg. UNFCCC ExCom, 2016, 2017). It is important to note that the theoretical financial efficiencies of sovereign risk pools would apply independent of any current or future change in climate risk profiles. However, the growing political salience, donor support, and country-buy in for these programs has hinged largely on projections of growing climate change impacts on a wide variety of extreme weather events, manifesting differently across spatial and temporal scales, including the frequency and/or intensity of floods, droughts, extreme temperatures, and tropical cyclones (eg. GIZ 2015, G7 2015).

Their rationale is expressly to counteract the limited ability of an individual nation to absorb losses. Given the small geographic and/or economic size of many of the countries with significant vulnerability to extreme events, average annual disaster losses consume a particularly large chunk of GDP - for Vanuatu, for instance, 6.5\% (World Bank, 2015). Likewise, states' meagre tax bases, indebtedness, and economic size limits their ability to borrow, reducing quick access to liquid cash for disaster response. Budgets typically hold meagre to nil in-country funds; the Solomon Islands, for example, has no reserves for disaster response (World Bank 2015). Once such funds and any contingency budgets are exhausted, states typically rely on protracted and uncertain appeals for international humanitarian aid. The result is that households and cashstrapped states ultimately absorb a large proportion of losses, exacerbating conditions of vulnerability.

\footnotetext{
${ }^{6}$ Until June 2016, PCRIC was not a separate insurance program but rather a component part of PCRAFI, The Pacific Catastrophe Risk Assessment and Financing Initiative.
} 
Sovereign risk pools are intended to fill this gap with an ex-ante insurance mechanism that is less costly than the equivalent emergency contingency funds that may drive countries further into debt. The ARC Agency, for instance, claims that the drought insurance cover members obtain through the pool is up to $50 \%$ less expensive than emergency borrowing (ARC, 2016a). Payouts are triggered either by prespecified metrics such as wind speed, rainfall, or ground acceleration, or by feeding these metrics into a model of projected losses that triggers above a certain threshold. The insurance cover provided by such pools is held by the states themselves, and is meant to finance countries' post-event relief and reconstruction (though the extent to which relief is intended for and/or reaches ordinary households varies greatly, see e.g. Grove, 2012 for a searing critique of CCRIF in this regard). ${ }^{7}$

\begin{tabular}{|c|c|c|c|c|c|c|}
\hline $\begin{array}{l}\text { Pool } \\
\text { Date founded }\end{array}$ & Risk transfer model & Pool Members & Perils & $\begin{array}{l}\text { Coverage } \\
\text { limit (in } \\
\text { USD) }\end{array}$ & $\begin{array}{l}\text { Total } \\
\text { Payouts } \\
\text { through } \\
\text { mid-2018 }\end{array}$ & $\begin{array}{l}\text { Notable Payouts } \\
\text { relative to size of } \\
\text { program }\end{array}$ \\
\hline $\begin{array}{l}\text { Caribbean } \\
\text { Catastrophe } \\
\text { Risk } \\
\text { Insurance } \\
\text { Facility } \\
\text { (CCRIF) }\end{array}$ & $\begin{array}{l}\text { Catastrophe risk to } \\
\text { international } \\
\text { reinsurance market } \\
\text { and capital markets }\end{array}$ & $\begin{array}{l}\text { 2018: } \\
\text { Anguilla; } \\
\text { Antigua \& Barbuda; } \\
\text { Bahamas; Barbados; } \\
\text { Belize; Bermuda; } \\
\text { British Virgin } \\
\text { Islands; } \\
\text { Cayman Islands; } \\
\text { Dominica; Grenada; } \\
\text { Haiti; Jamaica; } \\
\text { Monserrat; St. Kitts } \\
\text { \& Nevis; St. Lucia; } \\
\text { St. Vincent \& } \\
\text { Grenadines; Turks } \\
\text { \& Caicos; Trinidad } \\
\text { \& Tobago; } \\
\text { Nicaragua }\end{array}$ & $\begin{array}{l}\text { Tropical } \\
\text { cyclone; } \\
\text { earthquake; } \\
\text { excess rainfall }\end{array}$ & $\begin{array}{l}\text { 2016-17: } \\
\$ 724 \text { mil }\end{array}$ & $\$ 130.5 \mathrm{mil}$ & $\begin{array}{l}\text { 2017 Hurricane Irma } \\
\text { (\$30.8 mil): Anguilla, } \\
\text { Antigua \& Barbuda, } \\
\text { Bahamas, St. Kitts \& } \\
\text { Nevis, Turks \& } \\
\text { Caicos } \\
2017 \text { Hurricane } \\
\text { Maria (\$23.6 mil): } \\
\text { Barbados, Dominica, } \\
\text { St. Lucia, St. Vincent } \\
\text { \& Grenadines, Turks } \\
\text { \& Caicos } \\
\text { 2016 Tropical } \\
\text { cyclone Matthew } \\
\text { (\$29 mil): Haiti, St. } \\
\text { Lucia, Barbados } \\
\text { 2010 Earthquake } \\
\text { (\$7.7 mil): Haiti } \\
\text { 2010 Tropical } \\
\text { cyclone Tomas } \\
\text { (\$13.7 mil): St. } \\
\text { Vincent, Barbados, } \\
\text { St. Lucia }\end{array}$ \\
\hline $\begin{array}{l}\text { African Risk } \\
\text { Capacity }\end{array}$ & $\begin{array}{l}\text { Catastrophe risk } \\
\text { pooled to mutual }\end{array}$ & $\begin{array}{l}2017-2018 \\
\text { Burkina Faso }\end{array}$ & $\begin{array}{l}\text { Drought, } \\
\text { cyclone and }\end{array}$ & $\begin{array}{l}\text { 2015-16: } \\
\$ 179 \text { mil }\end{array}$ & $\$ 36$ mil & $\begin{array}{l}\text { 2016 drought (\$8.1 } \\
\text { mil): Malawi* }\end{array}$ \\
\hline
\end{tabular}

\footnotetext{
${ }^{7}$ In the case of ARC, in order to join the pool, countries must have approved contingency plans outlining the country's emergency response and specific channels by which disaster-affected populations will receive relief.
} 


\begin{tabular}{|c|c|c|c|c|c|c|}
\hline $\begin{array}{l}\text { Agency } \\
\text { (ARC) } \\
\text { Specialized } \\
\text { agency of the } \\
\text { African Union }\end{array}$ & $\begin{array}{l}\text { sovereign insurance } \\
\text { company ARC Ltd, } \\
\text { some passed to } \\
\text { international } \\
\text { reinsurance market }\end{array}$ & $\begin{array}{l}\text { Mali } \\
\text { Mauritania } \\
\text { Senegal } \\
\text { The Gambia }\end{array}$ & flood planned & & & $\begin{array}{l}\text { 2014-15 Sahel } \\
\text { drought ( } \$ 26 \text { mil): } \\
\text { Senegal, Mauritania, } \\
\text { Niger }\end{array}$ \\
\hline $\begin{array}{l}\text { Pacific } \\
\text { Catastrophe } \\
\text { Risk } \\
\text { Insurance } \\
\text { Company } \\
\text { (PCRIC, } \\
\text { formerly } \\
\text { PCRAFI) }\end{array}$ & $\begin{array}{l}\text { Currently: captive } \\
\text { insurance facility } \\
\text { owned by member } \\
\text { countries passes risk } \\
\text { to international } \\
\text { reinsurance market } \\
\text { Initially: catastrophe } \\
\text { swap contracts to } \\
\text { international } \\
\text { reinsurance market }\end{array}$ & $\begin{array}{l}\text { 2017-2018: } \\
\text { Cook Islands } \\
\text { Marshall Islands } \\
\text { Samoa } \\
\text { Tonga } \\
\text { Vanuatu }\end{array}$ & $\begin{array}{l}\text { Tropical } \\
\text { cyclone; } \\
\text { earthquake/ } \\
\text { tsunami }\end{array}$ & $\begin{array}{l}\text { 2017-18: } \\
\text { \$45 mil }\end{array}$ & $\$ 6.7 \mathrm{mil}$ & $\begin{array}{l}2018 \text { Tropical } \\
\text { Cyclone Gita (\$3.5 } \\
\text { mil): Tonga } \\
2015 \text { Tropical } \\
\text { Cyclone Pam ( } \$ 1.9 \\
\text { mil): Vanuatu } \\
\text { 2014 Tropical } \\
\text { Cyclone Ian ( } \$ 1.3 \\
\text { mil): Tonga }\end{array}$ \\
\hline
\end{tabular}

Table 1: Overview of extant sovereign disaster insurance pools

The organizing logic of such pools is that stretching risk's spaces will allow many small countries to present a combined portfolio to reduce the cost of reinsurance capital. The savings accrue via at least two mechanisms: geographic diversification of risk, by which premiums from one territory offset losses in another; and reduced transaction costs due to coordinated portfolio modeling and contract negotiation. CCRIF suggests member states' insurance premiums are roughly 50\% less than if purchased individually at a standard market cost (UNFCCC ExCom, 2017:41).

All three pools have made post-disaster disbursements (see Table 1), though payouts still comprise a relatively minor percentage of total disaster financing. Although the scale of payouts has not corresponded with the magnitude of each disaster given the low levels of coverage purchased, the ostensible appeal of the sovereign risk pool model is its rapid disbursements for financing immediate response and recovery activities. Though CCRIF and PCRAFI's payouts were disbursed to governments within 10-14 days of triggering events, ARC's payouts have been delayed. In one case (Malawi) an inaccurately modelled representation of the drought event meant the contract failed to trigger initially (ActionAid, 2017); in others 
(Senegal, Mauritania, Niger), ARC withheld funds until countries provided more clearly specified relief implementation plans (DFID, 2015).

Perhaps the biggest "success" of sovereign pools has been in their flexibility as a financial model bridging vastly different geographies with distinct political economies, territorial arrangements, and hazard profiles. The sovereign pool model launched with CCRIF in 2007, and by the Copenhagen climate meetings in 2009, CCRIF was championed as a model for other regions to emulate (Young, 2010). PCRAFI modified CCRIF's model to pool catastrophe swap contracts beginning in 2013; in 2016 this model evolved into the captive insurance facility PCRIC (World Bank, 2016b). One of the founders of CCRIF went on to act as the first chief executive of ARC Insurance Company Limited in 2014. By 2016, CCRIF was building a new Central American pool and outlined its larger ambitions to "be the world's global risk insurance facility for hazards faced by small island and coastal states - to become G-CRIF” (CCRIF, 2016:6).

Yet stretching risk's scales even across states sharing some regional identity can be logistically and politically thorny. A recent UNFCCC report suggested the "high degree of regional cooperation and solidarity" required is the primary challenge to regionally aggregating transboundary risks (UNFCCC ExCom, 2016:6). To even constitute risk such that it meaningfully indexes broader spatialities requires bureaucratic and budgetary alignment across the pool, potentially challenging sovereign authority. PCRAFI's five initial participating countries struggled to complete administrative and budgetary approval steps on schedule, resulting in delayed coverage that missed the beginning of the Pacific cyclone season by over two months. Bureaucratic delays have knock-on costs as reinsurers charge higher relative risk prices to recoup transaction costs (World Bank, 2015).

The strength of regional solidarity implied in such risk pools is constrained by countries' own limited financial means and the limitations and renewal procedures of the pools themselves. For instance, the Solomon Islands left PCRAFI in the third year of the pilot after no payouts were triggered by an 8.0 earthquake in a remote (expensive to access) location, nor by flash flooding from a tropical depression that generated $\$ 108$ million in losses - 9\% of GDP. In neither case did an error of measurement or calculation obstruct a payout; the problem lay in the limits of the policy structure itself. Tropical depressions were not 
included in the contractual coverage, nor was earthquake damage in remote locations with low economic losses; both limits were driven by the need to balance adequate coverage against modelling capacity and feasible pricing (World Bank, 2015). The Solomon Islands' departure from the pool highlights the contingency of both the geographical and temporal scale of the pool's engineered solidarity. Similarly, the 2016-2017 ARC risk pool lost two members of the previous year's pool, Malawi and Kenya. Malawi did not renew following a drought in 2016, the severity of which ARC's model failed to represent (for a damning account, see ActionAid, 2017). Although ARC eventually made a payout to Malawi after revising model parameters, the money arrived nine months after the government had declared a national emergency. ARC revoked Kenya's offer of insurance after the country delayed signing the policy; there appear to have been disagreements about discrepancies between ARC's modelled drought conditions and conditions observed on the ground by Kenya's National Drought Management Authority.

Earlier, we suggested that the constitution of mutualities depends on tethering futures together over a longer time horizon, yet the institutionalized annual nature of catastrophe insurance renewals means that members can choose to exit the pool at the end of every year. Such "renewable solidarity" is likely to deteriorate if countries feel they were wrongly denied a payout, or others benefitted inordinately. National election cycles also influence participation; payouts must be frequent enough to appear in a 4-5 year timeframe lest those in power be accused of squandering scarce funds. Annual budget cycles and competing needs lead to an ever-changing risk pool. Rather than growing to a targeted 12-country pool in 2016, ARC shrunk to six, and then to five in 2017; an independent review noted that although "ARC is building a [technical] presence across Africa, the ARC insurance risk pool is shrinking rather than growing, raising concerns about the long-term viability of the organization" (ePact 2017b, ii). The review concluded that the chief long-term threat to the pool is countries' inability to consistently finance premium payments from national treasuries (a sentiment echoed by DFID, 2017:4).

Furthermore, the socialities constituted by these pools are far from universal, but rather reflect particular combinatory constellations of vulnerable territories peripheral to capital accumulation. This pooling of meager resources is the last resort of the vulnerable, rather than a cross-subsidized socialization of 
risk distribution. ${ }^{8}$ There are as yet no examples of cross-regional solidarity between countries who are not similarly situated; rather the risk pools are already by definition differentiated. Combinations have been assembled to make risk transfer financially accessible to these countries, but they also allow global reinsurance capital to diversify their loss exposures. Given that large volumes of catastrophe reinsurance coverage is written in so-called "peak peril" areas in North America and Europe, where a single event such as a Florida hurricane can force major payouts across many contracts, reinsurance capital is often keen to diversify to "non-peak" perils with little correlation to their major loss drivers (Johnson, 2014). ARC has consistently found a panoply of reinsurers - 24 at last count - eager to carry $\$ 53$ million of its portfolio exposure (DFID, 2017). Likewise one of PCRAFI's explicit goals was to "test global reinsurance appetite for sovereign risk of Pacific island states" (World Bank, 2015:31). The reinsurance demand for a non-peak Pacific portfolio was known to be strong in Japan, the home of the project's largest bilateral donor, the Japan International Cooperation Agency (JICA), and further financial support was provided by the Japanese Ministry of Finance.

Moving beyond the current model in which certain donors selectively subsidize premiums and/or technical assistance to particular regional pools, universal and complete solidarity would entail a formalized, permanent fund financed by wealthy countries in accordance with their accrued ecological debt (Warlenius et al, 2015) - the possibility of which was arguably dismantled in the Paris climate talks' explicit rejection of wealthy countries' responsibility for liability or compensation payments (UNFCCC, 2015). Indeed in the Marrakech climate talks a year later, ARC staff apparently took pride in the program's success getting African countries to pay their own premiums for their climate risk protection.

Finally, the extent to which a territory's risks can be rescaled to be borne by a broader sociality is highly dependent on the frequency profile of such risks. In the last several years, policy frameworks within the UN and World Bank have cohered around "comprehensive risk management" employing actuarial analysis to segregate risk layers and allocate them according to "risk preference" (UNFCCC ExCom, 2017; Mechler and Schinko, 2016). Here risk technologies allow sets of future loss events with frequencies and

\footnotetext{
${ }^{8}$ We thank an anonymous reviewer for this formulation.
} 
uncertainties deemed "tolerable" to insurance capital to be partitioned from those whose occurrence is too frequent or too inevitable, or whose magnitude is too extreme, to find a market willing to bear them (see Figure 1).

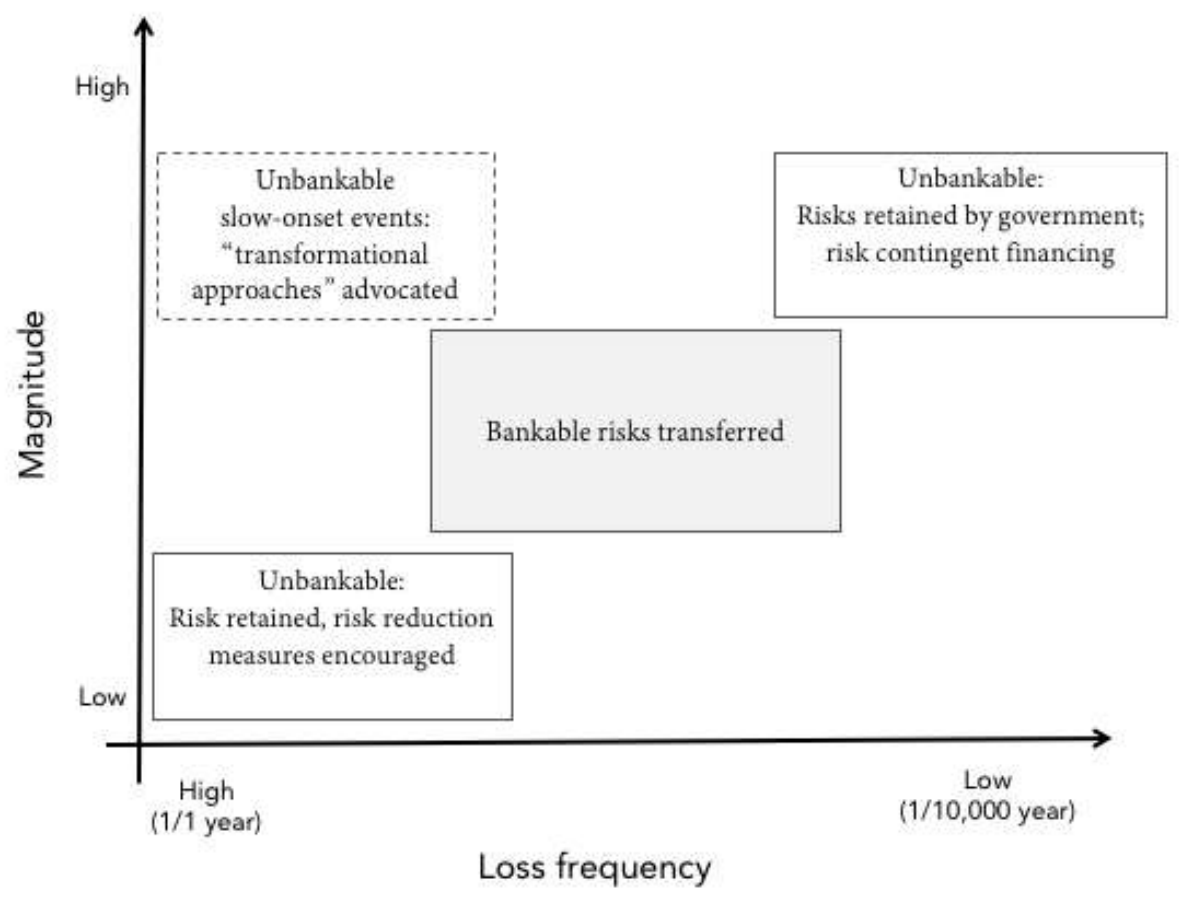

Figure 1: Typical "comprehensive risk management" approach, in which bankable risks with medium frequency and magnitude are transferred to (re)insurance markets. Following Mechler and Schinko, 2016; UNFCCC ExCom, 2017.

Frequent and small losses are unbankable by virtue of the high transaction costs relative to the sums insured, and certain and large risks are again unbankable and require extraordinary "transformational" responses like resettlement. For instance, the largest existential threat from climate change facing small island states is sea level rise. Yet this phenomenon will tend to trend upward for many island states (even if projecting exact magnitudes in particular locales is impossible due to uncertainty about interannual and interdecadal variability of regional sea levels, speed of ice sheet deterioriation, isostatic response to the loss of ice sheets, cf. Donner and Webber 2013). As such, it violates the basic insurance principle that events must be unpredictable and randomly distributed among a population. So while insurers will write coverage for extreme events such as tropical cyclones whose damages may be magnified by sea level rise, they will not insure against sea level rise itself. The absolute unbankability of an insurance response to slow-onset 
events such as sea level rise epitomizes the difficulty of stretching risk's spaces not just spatially, but also temporally: sea level rise is a risk materializing in slow(er)-motion, the accumulation of hundreds of years of fossil combustion and the inertia of the climate system. And when the outcome is slow and certain rather than quick and random, no willing buyers can be found: risk becomes a certainty to be brutally borne by territories and populations who must engage in "transformational adaptation" or cease to exist.

\section{Green bonds}

Insurance and equities related to climate have been relatively well explored from a political-economic perspective (e.g. Johnson, 2010, 2013; Lohmann, 2010, 2012), but debt, the largest global asset class by nominal value (Chappatta, 2016), remains largely unexamined (apart from Bracking, 2015). Labelled green bonds are institutional debt raised to finance or refinance assets that ostensibly form some component of a lower-carbon economy, ranging from public transport to energy efficient housing retrofits. The green label appears when the environmental aspects of a debt offering have been aligned with voluntary international guidelines, often verified by specialist assurance firms, ranging from CICERO, a Norwegian not-for-profit, to KPMG and Moody's. ${ }^{9}$

The aim of green bonds is to suture environmental and financial risk into return-generating commodities that can be either bought and held, or traded on secondary markets, and in doing so transform into climate finance the vast pools of capital warehoused by fixed income investors, like pension funds. Currently dedicated overwhelmingly to mitigation (Elders et al, 2018), green bonds are designed to reduce the risk of future climate-related externalities, rather than internalize the specific costs of those externalities, as in emissions markets (Felli, 2015). ${ }^{10}$ The expectation is that in lessening future environmental disruption they will also help to modulate attendant financial disruption. As Mark Carney, governor of the Bank of England, said in 2015, "risks to financial stability will be minimized if the transition [to a lower carbon

\footnotetext{
9 The Climate Bonds Initiative, an NGO that promotes green bonds, divides green debt into two categories: first, labeled green bonds, or debt that has been verified to comply with voluntary international guidelines for green-ness; and second, unlabeled, but 'climate aligned' debt that funds projects that would form some part of a climate-safe economy. The volume of unlabeled debt is about five times larger than the labeled volume of debt (CBI, 2017).

10 This is not to say that tradeable emissions permits necessarily do any internalizing (see Felli, 2014).
} 
economy] begins early and follows a predictable path" (quoted in Pitt-Watson, 2015), a transition to which the issuance of green debt is meant to be a key contributor. The green bond asset class constitutes financial risk across a range of heterogeneous state and non-state issuers, while tethering those actors to the global risk pool of current and future populations that will be impacted by climate change.

The commodification of risk in a green bond largely follows the same practices as the issuance of a normal bond, but with additional steps and actors meant to stitch climate risk to financial risk. In both 'vanilla' and green bonds, the embodied financial risk is that the borrower will not repay lenders, either in scheduled interest payments or when the principal becomes due at the end of the bond tenure. The quantification and pricing of this risk adheres to highly developed practices of the financial industry, relying on credit rating agencies, the pricing judgement of the underwriter, prevailing government interest rates, and buyers' models to judge the potential for default. The environmental risks commodified in green bonds are more diffuse, and the practices for evaluating these risks are still experimental when compared to methods for quantifying the financial risks of the same bonds, or for quantifying environmental risks tied to specific events, as in the case of sovereign catastrophe insurance pools. Nonetheless, we suggest that, in signaling a move to less polluting assets (re)financed through the use of labeled green debt, issuers shape new socialities of environmental risk aggregated across spatially and temporally distended people and institutions.

Climate change, by necessity, requires some level of 'globe talk' (Ley, 2004), even if the impacts are highly differentiated. This totalization may feel imprecise and (often) leads to mischaracterizations of globalness, particularly when climate change is reduced to cost-benefit logics devoid of equity and justice concerns, as evidenced, for example, by a 'social cost of carbon' that flattens impacts across space (e.g. Nordhaus, 2017). But it is not possible to discuss the risk pool constituted through mitigation efforts without conceptualizing at the level of the global, even while recognizing that different people and places bear different forms and magnitudes of environmental risks (and along with these, future economic risks posed by the cost of adaptation or lost revenue). The sociality over which such risks are constituted by the issuance of mitigation-oriented debt $i s$ global, even if it is a fairly weak form of sociality when compared with a mechanism like a national health insurance risk pool; even if, unlike under a welfare state insurance model, 
there is no cross-subsidization between the vulnerable and the less vulnerable; and even if it is highly unlikely that many, or maybe any, potential 'beneficiaries' of avoided emissions realize they are being constituted, time and time again, as members of that risk pool.

Here it is instructive to compare on the one hand the global risk pool constituted by green bonds for mitigation and, on the other, the risk sociality associated with finance for adaptation purposes, where stretched risk pools are less common because climate impacts vary from place to place and so adaptation must also vary spatially (and temporally). While the example of sovereign catastrophe insurance pools discussed above clearly does produce new socialities of risk bearing, we might think by contrast of the example of US municipal green bonds earmarked for adaptation, which entails a technology of risk segmentation. In one recently-discussed case, the improvement of Washington D.C.'s sewage system funded by a series of green bonds may help it cope with more frequent and severe rainfall events, but the risk pool those whose futures are corralled in and through the issuance of the debt - remains composed solely of those served by the municipal sewage system, who, as ratepayers, are also those who bear some financial risk of default as well as the costs of borrowing in the first place (Christophers, 2018).

The use of 'green' debt to raise money for emissions-reducing or avoiding projects was introduced by the European Investment Bank (EIB) in 2007 with its 'Climate Awareness Bond', a tactic that was replicated by other development banks, particularly the World Bank (WB). Starting as niche offerings, both the EIB and the WB have continued and expanded these borrow-to-lend programs, with the EIB raising US\$15 billion and the WB US\$10 billion by 2017 (EIB 2017; World Bank 2017). These totals are now dwarfed by the total sum of issuances, as labeled green debt reached nearly US\$155 billion in new issuances in 2017, including multi-billion-dollar bonds from municipalities, sovereigns, and the corporate sector (Elders et. al., 2018). A number of convergent factors have been key in driving this growth. First is the sheer volume of money required to pay for the transition to a lower-carbon economy, coupled with new infrastructure needed in the Global South and infrastructural retrofits needed in the Global North. The costs are truly staggering, measured in trillions over the coming decades (Fuerer, 2015). Meanwhile, vast sums of capital have accrued to the investor class, including in the accounts of pension funds in the Global North (discussed above) that 
face unfunded future liabilities but are restricted in the kinds of assets in which they can invest, both in terms of asset type and risk profile. Fixed income managers are searching for low (financial) risk assets but are also increasingly being pressured to consider the social and ecological ramifications of their investment choices (Ngo, 2016). Other existing climate financial mechanisms do not fit this profile. For example, the European Union Emissions Trading System has proven difficult to understand, volatile, and subject to political manipulation - hardly the type of investment that risk-averse pension fund managers find attractive. Thus, bonds that promise to take on some future environmental risks in the form of avoided climate instability are touted as an easily understood mechanism by which pools of 'vanilla' capital might be turned green.

For their proponents, one of the central draws of labelled green debt instruments is their similarity to vanilla bonds. However, issuers must enroll new actors to issue green debt, particularly verifiers of a bond's green credentials, and perhaps developing new in-house capacity to evaluate environmental impacts. For added surety, auditors may be hired to conduct ex-post evaluations of environmental performance. The modalities for assessing risk in a green bond vary between the financial and environmental component. On the one hand, there is a quantitative assessment of creditworthiness, either of the issuer or the project depending on the type of bond, represented by a familiar three-character rating produced by Moody's or S\&P (see Marron, 2007). On the other, a binary, yes/no judgement is issued by a second opinion provider as to whether, effectively, the proceeds raised by a bond will finance some component of a lower carbon future. ${ }^{11}$ While the scoring of financial risk resides on an AAA to BBB- scale, the mitigation of future environmental risks is for the most part simply ex-ante verified to be aligned with the activities proposed by the borrower, though ex-post reporting is becoming more common. As of 2017 there were 24 verifiers active in the green bonds space, each of which may take a different approach to signing off on a bond's potential to defray future environmental disruption.

\footnotetext{
${ }^{11}$ While this is usually a binary assessment, some verifiers of the environmental qualities of a given bond offer a 'shades of green' rating meant to guide purchasers on the quality of the environment benefits offered by projects, from dark green (fully aligned with a future green economy) to light green (better than nothing). See for example CICERO (2018). The extent to which shades of green ratings are performative, insofar as different shades of green engender different investment patterns, is unknown. It also bears noting that not all labelled green debt is evaluated on its potential to reduce climate risks. Reduced water usage, lower levels of industrial effluent, or a range of other criteria may be more appropriate for judging projects' environmental impact. However, greenhouse gas mitigation aims have dominated issuance thus far.
} 
There are a number of competing guidelines and standards against which the environmental bonafides of a debt offering can be assessed. These range from the Green Bonds Principles propagated by the International Capital Markets Association (ICMA, 2017), which is the most common and probably broadest baseline, to the Climate Bonds Standard, which sets a higher environmental bar and requires ongoing monitoring and reporting of environmental outcomes. While non-binding and extra-juridical, verification is an important aspect of a bond's origination and future distribution, as the verification that it adheres to these principles is a condition of acceptance onto most stock exchanges' green bond indices. Since the financial risk and the long-term climate risks associated with green bonds are evaluated separately, they only become formally co-constituted at the moment of issuance, rather than in their assessment. Environmental risk assessments are not linked to credit rating decisions. The verifier of environmental risks considers neither a company's balance sheet nor the economic prospects of the projects the debt is meant to finance.

In July 2017, a verifier of green credentials based in London told us that auditing by technical experts presents an opportunity to push for deeper emissions reductions in the projects to be funded by green debt. In this verifier's case, they would decline the business of potential issuers who may technically comply with issuance guidelines propagated by various industry groups, but who do not actively contribute to long-run decarbonization. In talking to clients, this verifier found it useful to encourage issuers to reflect on whether the proposed projects, as well as the issuers' overarching framework, complied with the 'Rockström model' - that is, becoming fully aware of climate impacts of business operations by 2020 , then a $50 \%$ reduction in greenhouse gas emissions each subsequent decade (Rockström et al., 2009). Thus, labeling may drive up individual issuers' ambitions and accordingly the decarbonization potential of the entire asset class, even if this cumulative potential is structurally constrained by the limits to decarbonization inherent to capitalism as we know it (Moore, 2015). Issuers are incentivized to take up the recommendations of the verifier because of the costs associated with verification, or the potential to fail to gain a verification, which would presumably contravene the issuer's strategy of labeling debt as green. To be sure, there are examples of labeled green debt that represent business-as-usual, such as is the case with manufacturers of wind turbines that have labeled their debt to appeal to a broader range of investors (see also DNV-GL, 2018). Nevertheless, 
additional layers of oversight and reflection introduce moments where a greater magnitude of shared future climate risk may be mitigated.

It bears noting that experience to date with green bonds varies substantially across sectors and geographies. Some emissions-intensive industries, particularly construction and agriculture, have been notably slow to adopt labeling practices. To succeed, moreover, bonds need to be bought as well as issued, and to the extent that green bonds imply at least some measure of solidarity - co-constituted risk - between current and future generations, they ask potential investors a rather fundamental question: Do responsibilities to future generations figure among your investment criteria? In some parts of the world the answer, increasingly, appears to be "yes." But in the United States, as the California State Treasurer John Chiang (California, 2016:10) observes, fiduciary responsibility "is generally viewed in narrow, short-run financial terms." This, surmises Chiang, may explain the "slower pace of development of the green bond market in the United States compared with Europe and other regions"; in the latter, fiduciary responsibility "may be defined more broadly to include social and environmental dimensions and long-term sustainability. The future costs of inaction on climate change may be part of the equation." While varying notions of fiduciary responsibility have a clear bearing on the distribution of risk through green bonds, they are critical to the origination of that risk as well. At the stage of origination, twinned environmental-financial risk is packaged to target particular buyers, influencing the currency in which it is issued, the extent of mitigation ambition inscribed in the project to be funded, and the stringency of environmental reporting to which an issuer will commit. If potential issuers do not believe there will be buyers for 'real' green debt providing real mitigation for a real global risk pool, they will not issue it as labelled green debt; the risks of greenwashing are rising and the costs of validation will be sunk, and they may simply issue the debt as per their normal borrowing practices.

At the end of the day, the 'success' of green bonds in constituting and shaping the futures of global risk pools is strictly relative. In green bond issuance, emissions reductions are meant to be driven by voluntary opt-in. This entirely elides genuine debate about what kinds of mitigation, and where, are most desirable for constituting solidarity between South and North, present and future. This question is, of course, 
political, and so requires the exact kinds of global dialog that have thus far failed to deliver meaningful emissions reductions - spurring instead the proliferation of the types of economistic approach to socialities of climate risk, like green bonds, examined here.

\section{Conclusion}

We have suggested in this article that one of the distinctive features of climate finance instruments such as sovereign catastrophe insurance pools and green bonds is their ventured stretching of the scales at which risk is constituted. This stretching, we showed, runs against the grain of dominant neoliberal modalities of financial commodification, where the prevailing tendency in recent decades has been to individualize risk and thus compress its scalar configuration. Insofar as it endeavours to constitute risk at broader temporal and spatial scales, climate finance faces significant obstacles of political, economic and logistical varieties. We have called attention to some of these, and illustrated how efforts to grapple with them are leading to considerable variegation in the ways and extent to which the risks corralled by climate finance are, in practice, actually being stretched.

In several respects the arguments contained in this article are provisional and limited, and necessarily so. Climate finance is not just a relatively immature financial sector but, by its very nature, a rapidly changing one. And even today it comes in many forms, deploying widely varying means towards an array of different ends; clearly we have examined only a subset of these forms, means and ends. So while we believe the dynamics highlighted in this article do potentially have a broader applicability in other areas of climate finance, and that comparable techniques of stretching are more widely mobilized within that domain, we hesitate to generalize too confidently beyond the particular financial instruments we have examined. Research into how risk is configured - socially, spatially and temporally - in other climate finance markets, including carbon markets, is clearly required.

One of the key issues we have highlighted is the question of inclusiveness, and here too further research is necessary. Not all climate-related risks are rescaled (still less "successfully"), and even those that are are typically characterised by social and spatial patchiness. Furthermore, in a world where both 
vulnerability to climate change and the financial wherewithal to deal with its consequences or contribute to mitigating it are highly unequally distributed, it is not difficult to imagine a bleakly territorialized future, further segmented by "risk appetite", where those who can afford local risks demarcate, privatize, and hedge geographic portfolios against one another, while others are left to fend for themselves in the face of more significant risks that they cannot afford - a future, in other words, of climate-financial exclusion. If "inclusive" rescaling is to prevail, the state will again, as in the era of postwar Keynesianism, have to step up to the plate. Whether it can do so - indeed, what "the state" will even look like in a globally-warmed future (Wainwright and Mann, 2018) - is of course a key question for the contemporary and future international political economy.

This brings us to the other main set of issues that requires further consideration. We have focused throughout, as noted at various points, on the scale of risk's constitution. The distribution of risk, and its spatio-temporality, has been beyond our remit. But it is clearly a crucial matter, and is clearly connected in significant ways to the question of constitution. As risk has increasingly been configured at the scale of the individual under neoliberalism, so too it has come increasingly to be borne by individuals, with governments and employers relinquishing historic risk burdens. If climate finance betokens a stretching of risk per se, what about the bearing of these reconfigured risks? Will their distribution abet a re-socialization of risk, or serve to frustrate it? These are key questions for geographers of financial markets, and others, to tackle in the years ahead. 


\section{References}

Alaskary T (2016) “African Risk Capacity” Presentation to the 2016 Forum of the Standing Committee on Finance of the UNFCCC: Financial instruments that address the risks of loss and damage associated with the adverse effects of climate change. Manila, Philippines, 5-6 September.

Altiparmakov N (2013) Is there an alternative to the pay-as-you-go pension system in Serbia? Economic Annals 58(198): 89-114.

ARC (2016a) "The Cost of Drought in Africa" Input to the UNFCCC Standing Committee on Finance Forum, 28 February. Available at: http://unfccc.int/files/cooperation_and_support/financial_mechanism/standing_committee/application/p df/arc cost of drought en.pdf Accessed 05 May 2017.

ARC (2016b) “ARC Overview” Input to the UNFCCC Standing Committee on Finance Forum, 28 February. Available at:

http://unfccc.int/files/cooperation_and_support/financial_mechanism/standing_committee/application/p df/arc_overview_brief_en.pdf Accessed 05 May 2017.

ARC (2016c) Press Release, 13 November: Malawi to receive USD 8M insurance payout from African Risk Capacity. Johannesburg: African Risk Capacity Insurance Company Limited.

ActionAid (2017) The wrong model for resilience: How G7-backed drought insurance failed Malawi, and what we must learn from it. Johannesburg: ActionAid.

Artemis (2018) World Bank pushes city climate resilience, with role for risk transfer. Artemis 4 January 2018. Available at http://www.artemis.bm/blog/2018/01/04/world-bank-pushes-city-climate-resiliencewith-role-for-risk-transfer/ Accessed 8 June 2018.

Artemis (2017) Parametric Pacific catastrophe facility upsizes at reinsurance renewal. Artemis 22 November 2017. http://www.artemis.bm/blog/2017/11/22/parametric-pacific-catastrophe-facility-upsizes-at$\underline{\text { reinsurance-renewal/ }}$

Bennett P (2009) Geographies of Financial Risk. In: Smith S, Pain R, Marston S and Jones J-P (eds) The SAGE Handbook of Social Geographies. London: Sage, pp.222-236. 
Blumberg L (2004) Addressing Adverse Selection in Private Health Insurance Markets, 22 September. Available at: http://www.urban.org/sites/default/files/publication/58366/900752-Addressing-AdverseSelection-in-Private-Health-Insurance-Markets.PDF. Accessed 4 August 2017.

Boyd E (2009) Governing the Clean Development Mechanism: global rhetoric versus local realities in carbon sequestration projects. Environment and planning A 41(10): 2380-2395.

Bracking S (2015) Performativity in the Green Economy: how far does climate finance create a fictive economy? Third World Quarterly 36(12): 2337-2357.

Bumpus A and Liverman D (2008) Accumulation by Decarbonization and the Governance of Carbon Offsets. Economic Geography 84: 127-155

California State Treasurers Office (2017). Growing the US Green Bond Market. Sacramento, CA: State of California.

CCRIF (2016) Caribbean Catastrophe Risk Insurance Facility SPC Annual Report 2015-2016. Cayman Islands: CCRIF SPC.

CCRIF (2017) Caribbean Catastrophe Risk Insurance Facility SPC Annual Report 2016-2017. Cayman Islands: CCRIF SPC.

Chappatta B (2016) The $\$ 100$ trillion bond market's got bigger problems than Brexit. Bloomberg Available at: https://www.bloomberg.com/news/articles/2016-06-26/the-100-trillion-bond-market-s-got-biggerconcerns-than-brexit Accessed 5 May 2017.

Christophers B (2015) Value models: Finance, risk, and political economy. Finance and Society 1(2): 1-22.

Christophers B (2018) Risk Capital: Urban political ecology and entanglements of financial and environmental risk in Washington, D.C. Environment and Planning: E. Online first.

CICERO (2018) ‘Second Opinion’ on Landshypotek Bank’s Green Bond Framework. Available at https://www.landshypotek.se/globalassets/dokument/finansiell-info/grona-obligationer/cicero-secondopinion-landhypotek-bank---final-09042018.pdf. Accessed 8 June 2018.

Climate Bond Initiative (2017) Green bonds highlights 2016. London: CBI. 
Collier S (2014) Neoliberalism and natural disaster: Insurance as political technology of catastrophe. Journal of Cultural Economy 7(3): 273-290.

Dean M (1998) Risk, calculable and incalculable. Soziale Welt 49: 25-42.

DFID (2015) 2014-15 Annual Review African Risk Capacity Programme. UK Department for International Development. Available at: https://devtracker.dfid.gov.uk/projects/GB-1-203469/documents

DFID (2017) 2016-17 Annual Review African Risk Capacity Programme. UK Department for International Development. Available at: https://devtracker.dfid.gov.uk/projects/GB-1-203469/documents

Donner S and Webber S (2013). Obstacles to climate change adaptation decisions: a case study of sea-level rise and coastal protection measures in Kirabati. Sustainability Science 9: 331-345.

DNV GL (2018). Scatec Solar Green Bond: DNV GL eligibility assessment. Available at: http://www.scatecsolar.com/content/download/973/14547/file/Eligibility\%2520Assessment_DNV\%252 0GL.pdf. Accessed 8 June 2018.

Elders G, Tyce J, Contractor S, and Patel J (2018) Blossoming green-bond market growing toward \$250 billion year. Bloomberg, 8 March 2018. Available at https://www.bloomberg.com/professional/blog/blossoming-green-bond-market-growing-toward-250billion-year/. Accessed 8 June 2018.

Environmental Finance (2018) Green Bond of the Year - Municipality \& Biggest issuer - Municipal: New York MTA. Available at https://www.environmental-finance.com/content/awards/green-bond-awards2018/winners/green-bond-of-the-year-municipality-and-biggest-issuer-municipal-new-york-mta.html. Accessed 19 June 2018.

Ericson R, Doyle A and Barry D (2003) Insurance as governance. Toronto: University of Toronto Press. e-Pact (2017a) Independent evaluation of the African Risk Capacity (ARC) Formative Phase 1 Report. Oxford: e-Pact Consortium, Oxford Policy Management and Itad.

e-Pact (2017b) Independent evaluation of the African Risk Capacity (ARC), Annex B: Organisational Review. Oxford: e-Pact Consortium, Oxford Policy Management and Itad. 
European Investment Bank (2017). CAB Newsletter $10^{\text {th }}$ Anniversary. Available at http://www.eib.org/attachments/fi/2017-cab-newsletter-10years.pdf. Last accessed 8 June 2018.

Ewald F (1991) Insurance and Risk. In: Burchell G, Gordon C and Miller P (eds) The Foucault Effect: Studies in Governmentality. Chicago: University of Chicago Press, pp.197-210.

Felli R (2014) On climate rent. Historical Materialism. 22(3-4), 251-280.

Felli R (2015) Environment, not planning: the neoliberal depoliticisation of environmental policy by means of emissions trading. Environmental Politics. 22:(5), 641-660.

French S (2009) Risk: mastering time and space. In: Clifford N, Holloway S, Rice S and Valentine G (eds) Key Concepts in Geography. London: Sage, pp.392-404.

Fuerer G (2015) How can we bridge the $\$ 1$ trillion infrastructure gap? World Economic Forum. Available at: https://www.weforum.org/agenda/2015/10/how-can-we-bridge-the-1-trillion-infrastructure-gap/ Accessed 6 May 2018.

G7 (2015) Joint Statement on InsuResilience: The Initiative on Climate Risk Insurance. Paris: Group of 7. 5 December. http://www.bmz.de/g7/includes/Downloadarchiv/G7_Joint_Statement_InsuResilience.pdf. Accessed 18 May 2018.

GIZ (2015) Climate risk insurance for strengthening climate resilience of poor people in vulnerable countries: A background paper on challenges, ambitions and perspectives. Eschborn: Deutsche Gesellschaft für Internationale Zusammenarbeit (GIZ). http://www.climateinsurance.org/fileadmin/mcii/pdf/G7_Climate-Risk-Insurance_Background-Paper.pdf. Accessed 18 May 2018.

Grove K. (2012) Preempting the next disaster: Catastrophe insurance and the financialization of disaster management. Security Dialogue 43: 139-155.

Hacker J (2004) Privatizing risk without privatizing the welfare state: The hidden politics of social policy retrenchment in the United States. American Political Science Review 98(2): 243-260.

Hacker J (2006a) The Great Risk Shift. Oxford: Oxford University Press. 
Hacker J (2006b) The Privatization of Risk and the Growing Economic Insecurity of Americans, 7 June.

Available at: http://privatizationofrisk.ssrc.org/Hacker/. Accessed 4 August 2017.

International Capital Markets Association (2017) The Green Bonds Principles 2017. Paris: ICMA.

International Energy Agency (2012) World Energy Outlook 2012. Paris: IEA.

Johnson L (2010) Climate change and the risk industry: the multiplication of fear and value. In Peet R, Watts M and Robbins, P. (eds) Global Political Ecology. London: Routledge, pp.185-202.

Johnson L (2013) Catastrophe bonds and financial risk: Securing capital and rule through contingency. Geoforum 45: 30-40.

Johnson L (2014) Geographies of securitized catastrophe risk and the implications of climate change. Economic Geography 90: 155-185.

Knight F (1921) Risk, Uncertainty and Profit. New York: Hart, Schaffner and Marx.

Knox-Hayes J (2013) The spatial and temporal dynamics of value in financialization: Analysis of the infrastructure of carbon markets. Geoforum 50: 117-128.

Lehtonen T and Liukko J (2015) Producing solidarity, inequality and exclusion through insurance. Res publica 21(2): 155-169.

Ley D (2004) Transnational spaces and everyday lives. Transactions of the Institute of British Geographers, 29: 151-164.

Lohmann L (2010) Uncertainty markets and carbon markets: Variations on Polanyian themes. New Political Economy 15(2): 225-254.

Lohmann L (2012) Financialization, commodification and carbon: the contradictions of neoliberal climate policy. Socialist register 48: 85-107.

MacKenzie D (2009) Making things the same: Gases, emission rights and the politics of carbon markets. Accounting, Organizations and Society, 34(3-4), 440-455.

Marron D (2007) 'Lending by numbers': credit scoring and the constitution of risk within American consumer credit. Economy and Society 36(1): 103-133. 
Martin R, Rafferty M, and Bryan D (2008) Financialization, risk and labour. Competition \& Change 12(2): 120-132.

Massey D (1991) The political place of locality studies. Environment and Planning A 23(2): 267-281.

Mechler R and Schinko T (2016) Identifying the policy space for climate loss and damage. Science 354: 290292.

Moore, J (2015). Capitalism and the Web of Life. London: Verso.

Müller B, Johnson L and Kreuer D (2017) Maladaptive outcomes of climate insurance in agriculture. Global Environmental Change 46: 23-33.

National Research Council (2015) Affordability of National Flood Insurance Program Premiums: Report 1. Washington, DC: The National Academies Press. https://doi.org/10.17226/21709. Accessed 10 June 2018.

Nordhaus W. 2017. Revisiting the social cost of carbon. PNAS. Available at https://doi.org/10.1073/pnas.1609244114. Accessed 10 June 2018.

Newell P, Boykoff M and Boyd E (2012) The New Carbon Economy: Constitution, Governance and Contestation. Oxford: Wiley-Blackwell.

Ngo M (2016) The differences between incorporating ESG into fixed income and equities. Environmentalfinance.com, 13 April 2016. Available at https://www.environmental-finance.com/content/analysis/thedifferences-between-incorporating-esg-into-fixed-income-and-equities.html. Accessed 7 June 2018.

Orenstein M (2008) The rise of pension privatization. In: Orenstein M (ed) Privatizing pensions. Princeton, NJ: Princeton University Press, pp.14-35.

PCRIC (2018) Tonga Receives Record Insurance Payout Following Cyclone Gita. Raratonga, Cook Islands: Pacific Catastrophe Risk Insurance Company. 20 February.

Prasch R (2004) Shifting risk: The divorce of risk from reward in American capitalism. Journal of Economic Issues 38(2): 405-12.

Pitt-Watson D (2015) 'Fossilist' finance blocks ‘clean trillion'. Financial Times 7 October 2015. Available at https://www.ft.com/content/dc5d09d2-6b65-11e5-8171-ba1968cf791a. Accessed 10 June 2018. 
Propper C, Rees H and Green K (2001) The demand for private medical insurance in the UK: a cohort analysis. The Economic Journal 111(471): 180-200.

Rockström J, Steffen W, NooneK, Persson Å, Chapin, III F S, Lambin E, Lenton T M, Scheffer M, Folke C, Schellnhuber H, Nykvist B, De Wit C A, Hughes T, van der Leeuw S, Rodhe H, Sörlin S, Snyder P K, Costanza R, Svedin U, Falkenmark M, Karlberg L, Corell R W, Fabry V J, Hansen J, Walker B, Liverman D, Richardson K, Crutzen P, and Foley J. (2009) Planetary boundaries: exploring the safe operating space for humanity. Ecology and Society 14(2): 32.

http://www.ecologyandsociety.org/vol14/iss2/art32/

Rodgers D (2009) Atlantic Crossings: Social Politics in a Progressive Age. Cambridge, MA: Harvard University Press.

Rose N (1996) The death of the social? Re-figuring the territory of government. Economy and Society 25(3): 327-356.

Stern NH (2007) The economics of climate change: the Stern review. Cambridge: Cambridge University Press.

UNFCCC Executive Committee of the Warsaw International Mechanism for Loss and Damage (2016) Best practices, challenges, and lessons learned from existing financial instruments at all levels that address the risk of loss and damage associated with the adverse effects of climate change. Bonn: UN Framework Convention on Climate Change.

UNFCCC Executive Committee of the Warsaw International Mechanism for Loss and Damage. (2017) Compendium on comprehensive risk management approaches. Bonn: UN Framework Convention on Climate Change.

UNFCCC (2015) Adoption of the Paris Agreement, United Nations Framework Convention on Climate Change 21st Conference of Parties, 12 December. FCCC/CP/2015/10/Add.1

Wainwright J and Mann G (2018) Climate leviathan: a political theory of our planetary future. London: Verso. 
Warlenius R, Pierce G and Ramasar V (2015) Reversing the arrow of arrears: The concept of "ecological debt" and its value for environmental justice. Global Environmental Change 30: 21-30.

Wigan D (2010) Credit risk transfer and crunches: Global finance victorious or vanquished? New Political Economy 15(1): 109-125.

World Bank. (2015) Pacific Catastrophe Risk Insurance Pilot: From design to implementation - some lessons learned. Washington, DC: The World Bank Group.

World Bank. (2016a) Press Release, 2 November: New insurance facility to boost natural disaster resilience in Pacific Island Countries. Washington, DC: World Bank Group.

World Bank. (2016b) PCRAFI Facility Phase II: Enhancing the financial resilience of Pacific Island Countries against natural disaster and climate risk. Washington, DC: World Bank Group.

World Bank (2017) World Bank Green Bonds Reach \$10 Billion in Funding Raised for Climate Finance. Washington, D.C.: The World Bank Group.

Wrathall DJ, Oliver-Smith A, Fekete A, et al. (2015) Problematising loss and damage. International Journal of Global Warming 8: 274-294.

Young S (2010) Haiti, the Caribbean Cat Risk Insurance Facility, and cat risk in the Caribbean. Presentation to the Reinsurance Association of America Catastrophe Modeling 2010 Forum: Probabilities and Possibilities. Orlando, FL: 9-11 February. 